\title{
SYNTHESIS OF $\triangle$-AMINOLEVULINIC ACID AND CHLOROPHYLL BY ISOLATED CHLOROPLASTS
}

\author{
by \\ C. GAMINI KANNANGARA \\ and \\ SIMON P. GOUGH \\ Department of Physiology, Carlsberg Laboratory \\ Gamle Carlsberg Vej 10, DK-2500 Copenhagen, Valby
}

Keywords: Plastids, barley, maize, spinach, glutamate substrate

\begin{abstract}
Plastids isolated from immature spinach and greening barley or maize leaves incorporate L-glutamate- ${ }^{-14} \mathrm{C}$ or $\alpha$ ketoglutarate- ${ }^{14} \mathrm{C}$ into $\delta$-aminolevulinate in the presence of levulinate. In its absence barley plastids incorporated L-glutamate- ${ }^{-14} \mathrm{C}$ into chlorophyll $a$. Optimal incorporation of label was obtained with plastids isolated and incubated in glycerol containing media. The half-life of the $\delta$-aminolevulinate forming activity of the plastids was 5 $\min$ at $22^{\circ} \mathrm{C}$ and 1 hour at $0^{\circ} \mathrm{C}$. In these plastid preparations $\delta$-aminolevulinate synthesis is stimulated by light, ATP and aerobic conditions. Experiments employing photosynthetic inhibitors and artificial electron donors indicate the light stimulation to be indirect by provision of ATP and reducing power. Aminooxyacetate, DL- $\beta$ hydroxyglutamate and glyoxylate inhibited the synthesis of $\delta$-aminolevulinate. In precursor competition experiments with $a$-ketoglutarate, L-glutamate is preferentially incorporated into $\delta$-aminolevulinate. The plastids formed nmolar quantities of chemically identifiable $\delta$-aminolevulinate.
\end{abstract}

\section{INTRODUCTION}

A prerequisite for further studies of the genetic regulation of chlorophyll biosynthesis $(9,13,21)$ is the isolation and characterization of the enzyme(s) converting glutamate into $\delta$ aminolevulinate (ALA) $(3,4)$. Recently it has been shown that ALA formation can be carried out by isolated intact immature chloroplasts of spinach (7) and cucumber $(19,20)$. In the present paper we demonstrate the synthesis of ALA from glutamate or $\alpha$-ketoglutarate by plastids from greening barley and maize seedlings. Cofactor requirements and other properties of the reaction are described and optimal conditions defined for the capacity of barley plastids to produce ALA in quantities which 
can be identified by absorption spectrophotometry and by chromatography of the pyrrole derivative. In the absence of levulinate these conditions were found to be suitable for the conversion of glutamate into chlorophyll. The information obtained has helped us to prepare an organelle-free system catalyzing ALA synthesis from glutamate. This is described in a companion paper.

\section{MATERIALS AND METHODS}

\subsection{Plant material}

Spinach was purchased at the local market or grown in experimental plots. Seeds of the barley cultivar Svaloffs Bonus and of the maize cultivar Leopard were germinated in moist Vermiculite and grown at 20 to $23^{\circ} \mathrm{C}$ for six days and eight days, respectively, in complete darkness. At this time the dark grown seedlings were illuminated for six hours with "Osram Fluora، fluorescent light.

\subsection{Chemicals}

a-ketoglutarate-1 $1{ }^{14} \mathrm{C}$ (specific activity, 57.4 $\mathrm{mCi} / \mathrm{mmole}$ ) and $\alpha$-ketoglutarate- $\mathrm{U}-{ }^{14} \mathrm{C}$ (specific activity, $254.5 \mathrm{mCi} / \mathrm{mmole}$ ) were obtained from New England Nuclear. L-glutamate-1 ${ }^{14} \mathrm{C}$ (specific activity, $55 \mathrm{mCi} / \mathrm{mmole}$ ) and L-glutamate- $\mathrm{U}-{ }^{14} \mathrm{C}$ (specific activity, $276 \mathrm{mCi} / \mathrm{mmole}$ ) were obtained from Radiochemical Centre, Amersham. L-glutamate- $4-{ }^{3} \mathrm{H}$ (specific activity, $30,000 \mathrm{mCi} / \mathrm{mmole}$ was purchased from Schwarz-Mann.

Aminooxyacetate was supplied by Sigma and DL- $\beta$-hydroxyglutamate by ICN Pharmaceuticals.

\subsection{General remark}

In the following sections we describe the optimal procedures found to date for ALA formation by isolated plastids. Some of the experimental results were obtained by other procedures and these are given with the respec- tive tables and figures. All operations were carried out at $0-5^{\circ} \mathrm{C}$.

\subsection{Homogenization of leaves and isolation of plastids}

The leaves are harvested, wrapped in aluminium foil and cooled in ice. About $150 \mathrm{~g}$ of leaves are homogenized in a modified Braun kitchen homogenizer (10) using about $300 \mathrm{ml}$ of medium. The composition of the homogenization medium is as follows: $0.6 \mathrm{M}$-glycerol, $0.1 \mathrm{M}$ Tricine, $3 \mathrm{~mm}-\mathrm{Ca}\left(\mathrm{NO}_{3}\right)_{2}$. The $\mathrm{pH}$ of the medium is adjusted to 7.9 with $\mathrm{NaOH}$.

The homogenate is squeezed through a nylón cloth ( $31 \mu \mathrm{mesh})$ and filtered through a layer of the same cloth. The filtrate is centrifuged at $1400 \mathrm{~g}$ for $5 \mathrm{~min}$ and the pellet suspended in the following: $0.3 \mathrm{M}$-glycerol, $0.1 \mathrm{M}$-Tricine, $50 \mathrm{~mm}$ $\mathrm{Na}_{2} \mathrm{HPO}_{4}, 1 \mathrm{mM}$-dithiothreitol, $\mathrm{pH} 7.9$ after adjustment with $\mathrm{NaOH}$. Uniform suspension of the pellet is achieved with a piece of nylon stocking attached to a glass rod. The starch at the bottom of the pellet is left behind. This procedure gives rather pure preparations of structurally intact plastids as observed by electron microscopy.

\subsection{Chlorophyll determination}

Chlorophyll is measured by the method of BRUINSMA (5).

\subsection{Assay for ALA synthesis by isolated plastids}

Isolated chloroplasts are incubated in a total volume of $2 \mathrm{ml}$ of suspension medium in a $50 \mathrm{ml}$ conical flask. Chloroplasts equivalent to 5 to $100 \mu \mathrm{g}$ chlorophyll (barley) are used. The incubation medium contains, in addition to the components of the suspension medium, $0.5 \mathrm{~mm}$ ATP, $0.5 \mathrm{mM}$ - CoA, $10 \mu \mathrm{M}$-sodium acetate, 10 $\mu \mathrm{M}-\mathrm{FAD}, 25 \mathrm{mM}$-sodium levulinate and $2.5 \mu \mathrm{Ci}$ of labelled substrate. The reaction mixtures are incubated at $22^{\circ} \mathrm{C}$ for 15 to 20 min under either bright light (Philips HLRG $400 \mathrm{~W}$ at a distance of $20 \mathrm{~cm}$ ) or, less intense light, two $20 \mathrm{~W}$

Abbreviations: ALA $=\delta$-aminolevulinate, $\mathrm{CCCP}=$ carbonyl cyanide 3-chlorophenylhydrazone, $\mathrm{DCMU}=3-(3,4-$ dichlorophenyl)-1,1-dimethylurea, DCPIP = 2,6-dichlorophenolindophenol, PMS = phenazine methosulphate, TMPD = N, N, $\mathbf{N}^{1}, \mathbf{N}^{1}$-tetramethyl-p-phenylenediamine. 
"Osram Fluora fluorescent strip lights at a distance of $40 \mathrm{~cm}$. Incubations are terminated by $100 \mu \mathrm{l}$ of $70 \%$ ice-cold perchloric acid after cooling the flask in ice and adding $100 \mu \mathrm{g}$ carrier ALA. Labelled ALA formed was purified by Dowex cation exchange chromatography and after conversion into pyrrole, analysed by thin layer chromatography and spectrophotometry as previously described (7).

\subsection{Assay for chlorophyll synthesis by isolated plastids}

Plastids are incubated as for ALA synthesis except that levulinate is omitted. The incubations are terminated by the addition of acetone at $-20^{\circ} \mathrm{C}$ to give a final acetone concentration of $80 \%$. The precipitate formed is centrifuged off and the acetone solution reduced to about $3 \mathrm{ml}$ under a stream of nitrogen in dim light. The $\mathrm{pH}$ of the solution is at this stage 7.9. It is extracted three times with ether and the aqueous rest retained. The ether extracts are pooled, dried with anhydrous $\mathrm{Na}_{2} \mathrm{SO}_{4}$ and evaporated to dryness under a stream of nitrogen. This residue is referred to as the $\mathrm{pH} 7.9$ ether extract. The aqueous rest after the ether extractions is adjusted to $\mathrm{pH} 5.5$ and reextracted three times with ether. The extracts are then pooled, dried and evaporated to dryness as before. The residue is referred to as the $\mathrm{pH} 5.5$ ether extract.

The $\mathrm{pH} 7.9$ ether extract contains most of the green and yellow pigments, while the $\mathrm{pH} 5.5 \mathrm{ex}-$ tract contains a fraction of the more polar porphyrins if the latter are present. The following chromatographic systems are used to analyse the ether extracts.

1) Silica gel impregnated glass fibre sheets (Gelman ITLC SA) are run with a solvent of lutidine, water and $25 \%$ ammonia $89: 13: 1, \mathrm{v} / \mathrm{v} / \mathrm{v}$ in an ammonia atmosphere. This system approximates that of GoUGH (6) for the separation of porphyrins and is used without equilibration.

2) Mannitol thin layer plates are run with a solvent of $0.5 \%$ propanol in petroleum ether $\left(40^{\circ}\right.$. $\left.60^{\circ} \mathrm{C}\right)(16)$.

3) For cellulose thin layer plates a solvent is used consisting of petroleum ether $\left(40^{\circ}-60^{\circ} \mathrm{C}\right)$, benzene, acetone, $4: 1: 0.5, \mathrm{v} / \mathrm{v} / \mathrm{v}$, according to Holden (8).

Removal of $\mathrm{Mg}$ and phytol from chlorophyll $a$ is done in the following way. Chlorophyll $a$ is eluted from the mannitol plate with ether and the ether evaporated under a stream of nitrogen. The chlorophyll $a$ is redissolved in a small volume of chloroform and this then dissolved in a larger volume of $5 \% \mathrm{H}_{2} \mathrm{SO}_{4}$. The solution is left overnight in the dark at room temperature. The next day the hydrolysis products are extracted with chloroform. The extract is washed with $\mathrm{H}_{2} \mathrm{O}$, the chloroform phase retained and dried down under a stream of nitrogen. The residue is taken up in a small volume of acetone and chromatographed with system 3. The pheophorbide and pheophytin bands are eluted with $80 \%$ acetone and analysed.

Radioactivity on chromatograms is detected using a Packard 7201 radiochromatogram scanner and pigments identified and quantified using an Aminco DW2-A spectrophotometer. The radioactivity in the pigments is determined with the Beckman liquid scintillation system using Dimilume-30 as scintillation fluid.

\section{RESULTS}

\subsection{The effect of different osmotica on synthesis of $\delta$-aminolevulinate by isolated plastids}

In our previous publication (7) on the formation of ALA by plastids isolated from immature spinach leaves we used a Ficoll, Dextran, sucrose containing HoNDA medium for isolation of the plastids and a sorbitol containing medium for the reaction mixture. In a series of experiments it was found that spinach and barley plastids responded specifically to various osmotica tried. Spinach plastids were most active in synthesizing ALA when isolated in the modified HONDA medium and suspended as well as incubated in a medium lacking an osmoticum or containing glycerol. Barley plastids were found to be most active when isolated and incubated in a medium containing glycerol.

A comparative experiment with spinach and barley is presented in Table 1 . High activity for incorporation of $\alpha$-ketoglutarate- $-{ }^{14} \mathrm{C}$ into ALA 
Table I

Effect of sorbitol in the incubation medium on the incorporation of $\alpha$-ketoglutarate- ${ }^{14} \mathrm{C}$ into $\mathrm{ALA}$.

\begin{tabular}{|c|c|c|}
\hline \multirow{2}{*}{$\begin{array}{l}\text { Osmoticum } \\
\text { None } \\
0.3 \mathrm{M} \text {-sorbitol }\end{array}$} & \multicolumn{2}{|c|}{$\begin{array}{c}\text { Spinach } \\
\text { cpm incorporated into } \\
\text { ALA }\end{array}$} \\
\hline & $\begin{array}{r}21,675 \\
4,583\end{array}$ & $\begin{array}{r}9,960 \\
32,027\end{array}$ \\
\hline
\end{tabular}

Spinach plastids were isolated from immature leaves in a modified Honda medium, (25 g Ficol- $400,50 \mathrm{~g}$ Dextran T-40, $25 \mathrm{~mm}$-Tricine, $0.25 \mathrm{M}$-sucrose, $10 \mathrm{mM}$ $\mathrm{MgCl}_{2}, 1$ litre $\mathrm{H}_{2} \mathrm{O}$, pH 7.9). Barley plastids were isolated from 6-day dark grown seedlings greened for 6 hours using $0.6 \mathrm{M}$-sorbitol, $0.1 \mathrm{M}$-Tricine, $3 \mathrm{mM}-\mathrm{Ca}$ $\left(\mathrm{NO}_{3}\right)_{2} \mathrm{pH}$ 7.9. Plastids were then incubated with or without $0.3 \mathrm{M}$-sorbitol in $0.1 \mathrm{M}$-Tricine, $0.1 \mathrm{M}-\mathrm{K}_{2} \mathrm{HPO}_{4}$, $1 \mathrm{~mm}$-dithiothreitol, $25 \mathrm{~mm}$-sodium levulinate, $\mathrm{pH} 7.9$ in a total volume of $2 \mathrm{mls}$ with $2.5 \mu \mathrm{Ci}$ substrate. The reaction mixture for spinach plastids contained 300 $\mu \mathrm{g}$ chlorophyll and $\alpha$-ketoglutarate-U- ${ }^{14} \mathrm{C}$ was the substrate, correspondingly for barley plastids $41 \mu \mathrm{g}$ chlorophyll and $a$-ketoglutarate- $1-{ }^{14} \mathrm{C}$ were used.

is found by spinach plastids in the absence of sorbitol, whereas barley plastids lost activity when sorbitol was withdrawn. This loss of activity was correlated with breakage of the plastids as observed by phase contrast microscopy. In barley, replacement of sorbitol with glycerol in the isolation, suspension and incubation media resulted in a ten-fold higher incorporation of labelled a-ketoglutarate or glutamate into ALA (Table II). Since sorbitol does not penetrate the outer evelope of plastids (15) it probably affects ALA labelling adversely, in spinach as well as barley plastids, by retarding the uptake of the labelled substrates into the organelle. The experiment presented in Table II also illustrates that isolated plastids incorporate $\alpha$-ketoglutarate better than glutamate into ALA.

Several other osmotica were studied with isolated barley plastids (Table III). Ethylene glycol, propylene glycol, sucrose or glucose in the isolation and incubation medium were equally as suitable as glycerol for obtaining good incorporation. Retaining the same osmoticum for both isolation and incubation medium was in most cases advantageous. Sodium chloride in the grinding medium gave fewer intact plastids as observed by phase contrast microscopy and we consider this to be the main reason for the low incorporation into ALA in the presence of this salt.

In the course of these studies it was also ascertained that dithiothreitol at $1 \mathrm{mM}$ was an optimal concentration for ALA forming activity.

\section{Table II}

The effect of replacing sorbitol with glycerol on the incorporation of labelled substrates into ALA by isolated barley plastids.

\begin{tabular}{|c|c|c|c|c|}
\hline \multicolumn{2}{|c|}{ Osmotic agent during } & $\begin{array}{l}\text { Chlorophyll } \\
\mu \mathrm{g}\end{array}$ & Labelled substrate & $\begin{array}{l}\text { cpm } \\
\text { incorporated } \\
\text { into ALA }\end{array}$ \\
\hline $0.6 \mathrm{M}$-sorbitol & $0.3 \mathrm{M}$-sorbitol & 25.9 & $\begin{array}{l}\alpha \text {-ketoglutarate- } 1-{ }^{-14} \mathrm{C} \\
\text { L-glutamate }-1{ }^{14} \mathrm{C}\end{array}$ & $\begin{array}{l}8,075 \\
4,709\end{array}$ \\
\hline $0.6 \mathrm{M}$-glycerol & $0.3 \mathrm{M}$-glycerol & 27.8 & $\begin{array}{l}\text { a-ketoglutarate-1-14 } \mathrm{C} \\
\text { L-glutamate- } 1-{ }^{14} \mathrm{C}\end{array}$ & $\begin{array}{l}79,386 \\
47,577\end{array}$ \\
\hline
\end{tabular}

Plastids were isolated from 7-day dark grown seedlings greened for $5 \frac{1}{2}$ hours. The isolation medium contained in addition to the osmotic agent $0.1 \mathrm{M}$-Tricine, $3 \mathrm{~mm} \cdot \mathrm{Ca}\left(\mathrm{NO}_{3}\right)_{2}$ and was adjusted to $\mathrm{pH} 7.9$ with $\mathrm{KOH}$. The incubation medium contained in addition to the osmotic agent $0.1 \mathrm{M}$-Tricine, $0.1 \mathrm{M}-\mathrm{K}_{2} \mathrm{HPO}_{4}, 1 \mathrm{mM}$-dithiothreitol, $25 \mathrm{mM}$ sodium levulinate, adjusted to $\mathrm{pH} 7.9$ with $\mathrm{KOH}$. Incubations were carried out for $15 \mathrm{~min}$ at $22^{\circ} \mathrm{C}$ in the bright light. 
Table III

The effect of different grinding and suspension media on the incorporation of L-glutamate-U_-14 $\mathrm{C}$ into ALA by isolated barley plastids.

\begin{tabular}{|c|c|c|}
\hline \multicolumn{2}{|c|}{ Osmotic agent in } & \multirow{2}{*}{$\begin{array}{l}\text { cpm incorporated } \\
\text { into ALA }\end{array}$} \\
\hline Grinding medium & Suspension medium & \\
\hline $0.6 \mathrm{M}$-glycerol & $\begin{array}{l}0.3 \mathrm{M} \text {-glycerol } \\
0.3 \mathrm{M}-\mathrm{NaCl} \\
0.3 \mathrm{M} \text {-sucrose }\end{array}$ & $\begin{array}{l}9,676 \\
4,630 \\
4,076\end{array}$ \\
\hline $0.6 \mathrm{M}-\mathrm{NaCl}$ & $\begin{array}{l}0.3 \mathrm{M}-\mathrm{NaCl} \\
0.3 \mathrm{M} \text {-glycerol }\end{array}$ & $\begin{array}{l}1,916 \\
3,356\end{array}$ \\
\hline $0.6 \mathrm{M}$-ethylene glycol & $0.3 \mathrm{M}$-ethylene glycol & 9,510 \\
\hline $0.6 \mathrm{M}$-propylene glucol & $0.3 \mathrm{M}$-propylene glycol & 9,150 \\
\hline $0.6 \mathrm{M}$-sucrose & $\begin{array}{l}0.3 \mathrm{M} \text {-sucrose } \\
0.3 \mathrm{M} \text {-glycerol }\end{array}$ & $\begin{array}{l}9,758 \\
5,940\end{array}$ \\
\hline $0.6 \mathrm{M}$-glucose & $0.3 \mathrm{M}$-glucose & 9,000 \\
\hline
\end{tabular}

Plastids were isolated from 5-day dark grown and 6 hours greened barley leaves. Grinding medium contained in addition to the compounds listed $0.1 \mathrm{M}$-Tricine, $3 \mathrm{mM}-\mathrm{Ca}\left(\mathrm{NO}_{3}\right)_{2}$ while the suspension medium contained in addition $0.1 \mathrm{M}$-Tricine, $0.1 \mathrm{M}-\mathrm{K}_{2} \mathrm{HPO}_{4}, 1 \mathrm{mM}$-dithiothreitol. All media had a pH of 7.9 adjusted with $\mathrm{KOH}$. Incubation media contained in addition to the components of suspension medium $25 \mathrm{~mm}$-levulinate, $0.5 \mathrm{~mm}-\mathrm{ATP}, 2.5 \mu \mathrm{Ci}$ $\mathrm{L}$-glutamate-U- ${ }^{14} \mathrm{C}, 4.9 \mu \mathrm{g}$ chlorophyll. Incubations were carried out in $2 \mathrm{ml}$ for $15 \mathrm{~min}$ at $22^{\circ} \mathrm{C}$ in light.

\subsection{Stability of the ALA synthesizing system in isolated plastids}

Increasing concentrations of barley chloroplasts up to an equivalent of $125 \mu \mathrm{g}$ chlorophyll in the incubation mixture progressively raised the incorporation of $\alpha$-ketoglutarate-U- ${ }^{14} \mathrm{C}$ into ALA (Figure 1). At higher chloroplast concentrations substrates or cofactors become limiting. At a given concentration ALA accumulation increases up to about $15 \mathrm{~min}$ of incubation and then levels off (Figure 2). In order to determine the stability of the enzyme in isolated barley plastids, they were preincubated at $22^{\circ} \mathrm{C}$ for times varying between 0 and $45 \mathrm{~min}$ in a reaction mixture without labelled substrate. Radioactive glutamate was then added and the incorporation of label into ALA after 15 min of incubation determined (Figure 3). Plastids lost one half of their capacity to incorporate Lglutamate-U-14 $\mathrm{C}$ into ALA when preincubated for $5 \mathrm{~min}$. If the plastids were stored on ice in suspension medium without cofactors the decline of ALA synthesizing activity was slower and its half-life increased to 1 hour (Figure 4).

The morphology of the plastids, as observed by electron microscopy, at the beginning and end of a $15 \mathrm{~min}$ incubation in glycerol medium is shown in Figures 5 and 6. Before and after incubation the envelopes of the plastids were structurally intact and few contaminating mitochondria and bacteria were present. The loss of the ability to form ALA can thus not be due to disintegration of the chloroplasts, for instance by loss of the outer envelope. Incubation of the plastids in glycerol medium at $22^{\circ} \mathrm{C}$ for $15 \mathrm{~min}$ in the light caused an increasing number of invaginations of the inner chloroplast membrane and the formation of large electron transparent cavities (Figure 6). Further studies are required to elucidate if these structural changes are related to the declining activity of the plastids. 


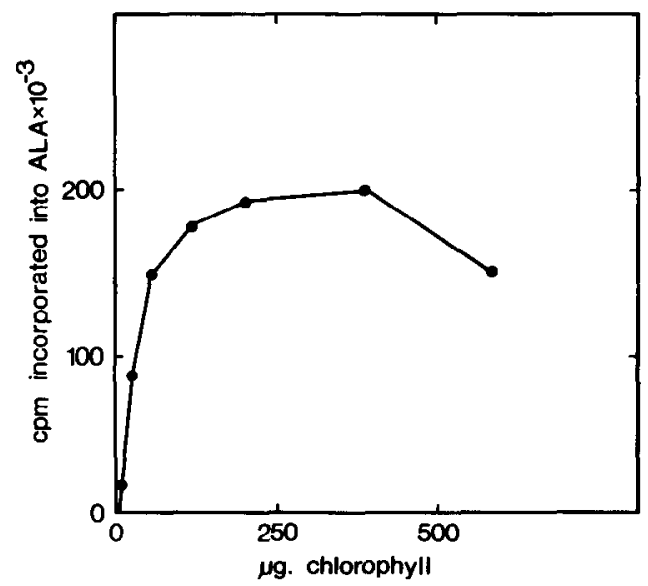

Figure 1. The effect of chloroplast concentration on the incorporation of $\alpha$-ketoglutarate- $\mathrm{U}-{ }^{14} \mathrm{C}$ into ALA by barley plastids. Plastids were isolated from barley seedlings grown in the dark for 6 days and then greened for 6 hours. The isolation medium was $0.6 \mathrm{M}$ glycerol, $0.1 \mathrm{M}-\mathrm{Tricine}, 3 \mathrm{mM}-\mathrm{Ca}\left(\mathrm{NO}_{3}\right)_{2}$, adjusted to $\mathrm{pH} 7.9$ with $\mathrm{KOH}$. Incubations were carried out in 50 $\mathrm{ml}$ flasks containing $2 \mathrm{ml}$ of the following: $0.3 \mathrm{M}$ glycerol, $0.1 \mathrm{M}-\mathrm{Tricine}, 0.1 \mathrm{M}-\mathrm{K}_{2} \mathrm{HPO}_{4}, 1 \mathrm{mM}$ dithiothreitol, $25 \mathrm{~mm}$-sodium levulinate, $0.5 \mathrm{mM}$-ATP. $0.5 \mathrm{~mm}-\mathrm{CoA}, 1 \mathrm{mM}-\mathrm{MgCL}_{2}, 10 \mu \mathrm{M}$-sodium acetate, 10 $\mu \mathrm{M}-\mathrm{FAD}, 2.5 \mu \mathrm{Ci}$ of $\alpha$-ketoglutarate-U- ${ }^{14} \mathrm{C}$, adjusted to $\mathrm{pH} 7.9$ with $\mathrm{KOH}$, and various amounts of chloroplasts.

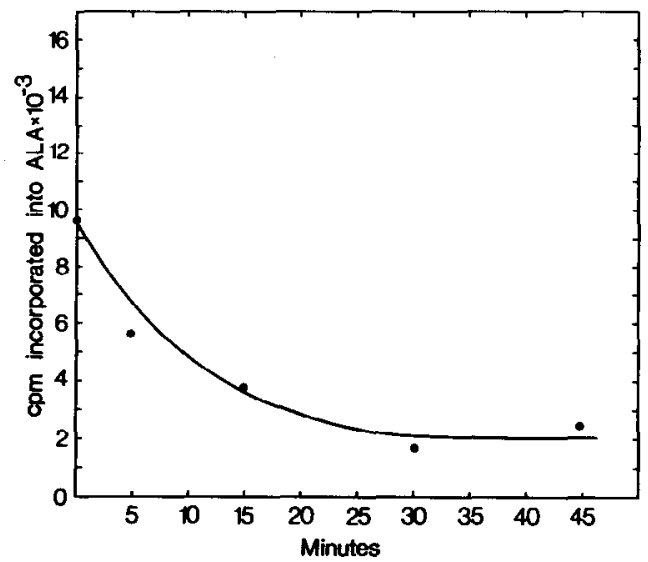

Figure 3. The decay of ALA-synthesizing ability of barley plastids in the incubation medium at $22^{\circ} \mathrm{C}$. Plastids were isolated from 5-day dark grown barley plants which had been greened for 6 hours. The isolation medium was $0.6 \mathrm{M}$-glycerol, $0.1 \mathrm{M}$-Tricine, 3 $\mathrm{mM}-\mathrm{Ca}\left(\mathrm{NO}_{3}\right)_{2}$ adjusted to $\mathrm{pH} 7.9$ with $\mathrm{KOH}$. Incubations were carried out in plastic $10 \mathrm{ml}$ tubes containing $2 \mathrm{ml}$ of $0.3 \mathrm{M}$-glycerol, $0.1 \mathrm{M}$-Tricine, $0.1 \mathrm{M}$ $\mathrm{K}_{2} \mathrm{HPO}_{4}$, adjusted to $\mathrm{pH} 7.9$ with $\mathrm{KOH}$ and also containing $25 \mathrm{~mm}$-sodium levulinate, $0.5 \mathrm{mM}$-ATP, 2.5 $\mu \mathrm{Ci}$ L-glutamate-U-14 $\mathrm{C}$ and $4.9 \mu \mathrm{g}$ chlorophyll. The tubes were preincubated in bright light without label for various times, the label was then added and the samples incubated for another 15 minutes.

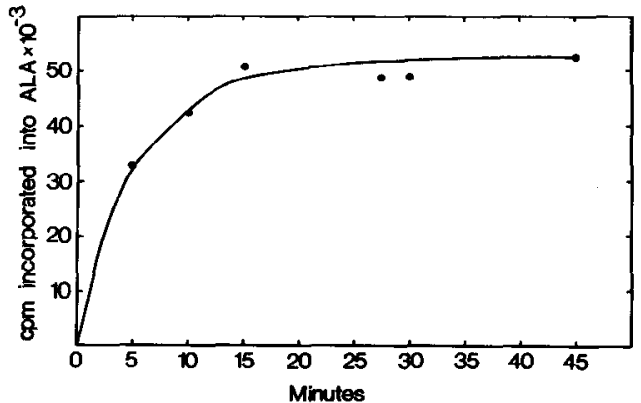

Figure 2. The time course of the incorporation of $\alpha$ ketoglutarate- $1{ }^{-14} \mathrm{C}$ into ALA by barley plastids. Plastids were isolated from barley plants grown in the dark for 6 days and greened for 7 hours using a medium consisting of $0.6 \mathrm{M}$-sorbitol, $0.1 \mathrm{M}$-Tricine, 3 $\mathrm{mM}-\mathrm{Ca}\left(\mathrm{NO}_{3}\right)_{2}$, adjusted to $\mathrm{pH} 7.9$ with $\mathrm{KOH}$. Incubations were carried out in a volume of $2 \mathrm{ml}$ in a 50 $\mathrm{ml}$ flask. The incubation mixture which was adjusted to $\mathrm{pH} 7.9$ with $\mathrm{KOH}$ contained $0.3 \mathrm{M}$-sorbitol, $0.1 \mathrm{M}$ Tricine, $0.1 \mathrm{M}-\mathrm{K}_{2} \mathrm{HPO}_{4}, 1 \mathrm{mM}$-dithiothreitol, $25 \mathrm{~mm}$ Na-levulinate, $2.5 \mu \mathrm{Ci} \alpha$-ketoglutarate and $186^{\circ} \mu \mathrm{g}$ chlorophyll. Incubations were carried out at $22^{\circ} \mathrm{C}$ under the bright light source.

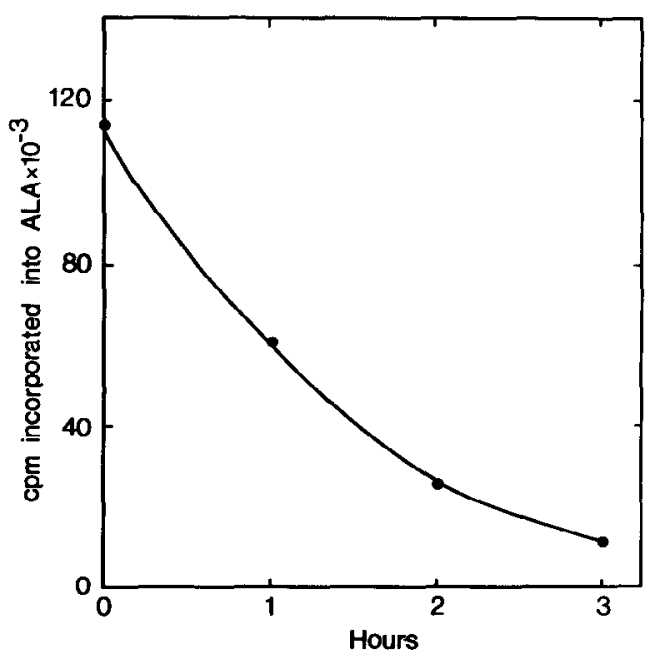

Figure 4. The decay of ALA-synthesizing ability of barley plastids in a $0.3 \mathrm{M}$-glycerol medium at $0^{\circ} \mathrm{C}$. Plastids were isolated from 6 day dark grown barley which had been greened for 6 hours. The isolation medium was $0.6 \mathrm{M}$-glycerol, $0.1 \mathrm{M}$-Tricine, $3 \mathrm{mM}$ $\mathrm{Ca}\left(\mathrm{NO}_{3}\right)_{2}$ adjusted to $\mathrm{pH} 7.9$ with $\mathrm{KOH}$. Plastids were suspended and stored for various times at $0^{\circ} \mathrm{C}$ in 0.3 M-glycerol, 0.1 M-Tricine, $0.1 \mathrm{M}-\mathrm{K}_{2} \mathrm{HPO}_{4}, 1 \mathrm{~mm}$ dithiothreitol, adjusted to $\mathrm{pH} 7.9$ with $\mathrm{KOH}$. Incubations for $20 \mathrm{~min}$ were carried out in $50 \mathrm{ml}$ flasks containing $2 \mathrm{ml}$ of $0.3 \mathrm{M}$-glycerol, $0.1 \mathrm{M}$-Tricine, 0.1 $\mathrm{M}-\mathrm{K}_{2} \mathrm{HPO}_{4}$, adjusted to $\mathrm{pH} 7.9$ with $\mathrm{KOH}$ and also containing $25 \mathrm{~mm}$-sodium levulinate, $0.5 \mathrm{~mm}$ - ATP, $0.5 \mathrm{~mm}-\mathrm{CoA}, 1.0 \mathrm{mM}-\mathrm{MgCl}_{2}, 10 \mu \mathrm{M}$-sodium acetate, $10 \mu \mathrm{M}-\mathrm{FAD}, 2.5 \mu \mathrm{Ci}$ L-glutamate-1-14 $\mathrm{C}$ and $101 \mu \mathrm{g}$ chlorophyll. 


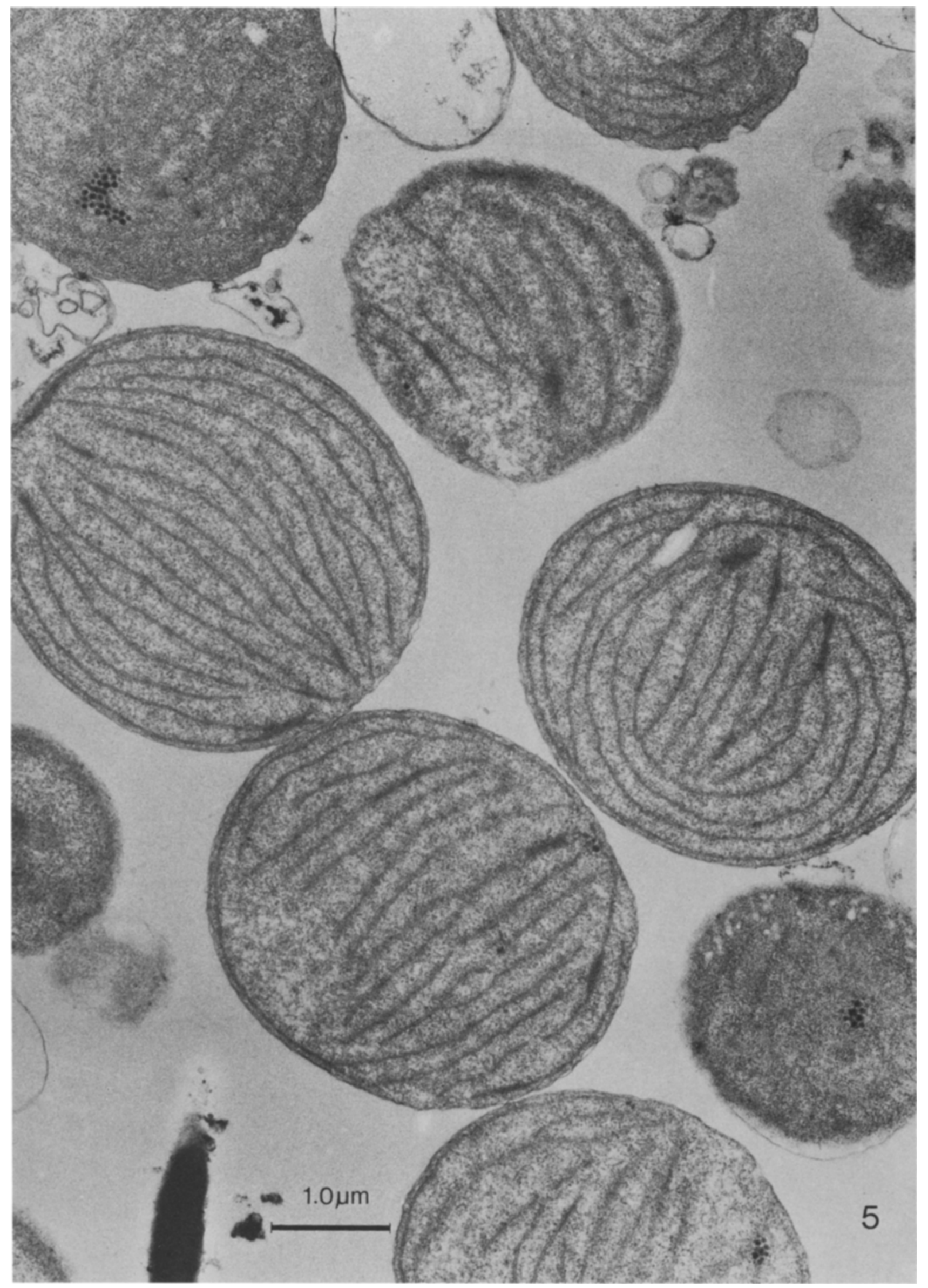




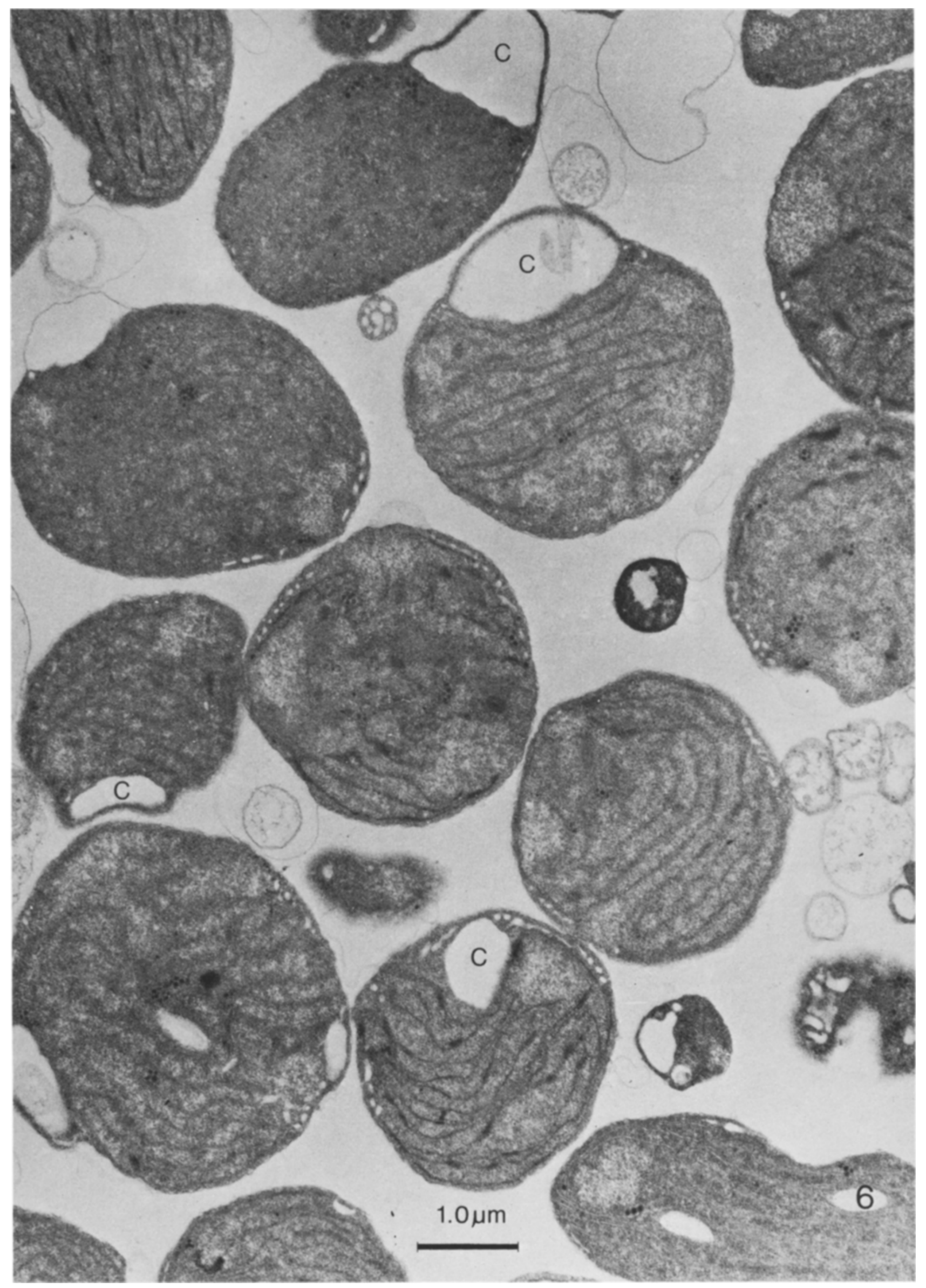


Figure 5. Morphology of greening barley plastids isolated in glycerol medium. The plastids were isolated from barley seedlings grown in the dark for 6 days and then greened for 6 hours. The isolation medium was $0.6 \mathrm{M}$ glycerol, $0.1 \mathrm{M}$-Tricine, $3 \mathrm{mM}-\mathrm{Ca}\left(\mathrm{NO}_{3}\right)_{2}$ adjusted to $\mathrm{pH} 7.9$ with $\mathrm{KOH}$. The plastids were suspended at $0^{\circ} \mathrm{C}$ in 0.3 M-glycerol, $0.1 \mathrm{M}$-Tricine, $0.1 \mathrm{M}-\mathrm{K}_{2} \mathrm{HPO}_{4}, 1 \mathrm{mM}$-dithiothreitol, adjusted to $\mathrm{pH} 7.9$ with $\mathrm{KOH}$. The plastids were fixed by suspending an aliquot of $0.2 \mathrm{ml}$ in $2 \mathrm{ml} 2 \%$ glutaraldehyde in suspension medium. Osmication, dehydration, embedding, sectioning and electron micrography were carried out according to standard procedures, Magnification $\times 22,200$.

Figure 6. Morphology of representative field of greening barley plastids after isolation in glycerol medium and incubation in reaction mixture for ALA synthesis for $15 \mathrm{~min}$ at $22^{\circ} \mathrm{C}$. The plastids were from the same preparation as those depicted in Fig. 5 but incubated in $0.3 \mathrm{M}$-glycerol, $0.1 \mathrm{M}-$ Tricine, $0.1 \mathrm{M}-\mathrm{K}_{2} \mathrm{HPO}_{4}, 1 \mathrm{mM}$-dithiothereitol, adjusted to $\mathrm{pH} 7,9$ with $\mathrm{KOH}$ and also containing $25 \mathrm{~mm}$-sodium levulinate, $0.5 \mathrm{~mm}$-ATP, $0.5 \mathrm{~mm}-\mathrm{CoA}, 1.0 \mathrm{mM}$ $\mathrm{MgCl}_{2}, 10 \mu \mathrm{M}$-sodium acetate, $10 \mu \mathrm{M}-\mathrm{FAD}, 5 \mu \mathrm{M}$-L-glutamate. Magnification $\times 18,500$. C, large cavities.

\subsection{Cofactor requirements for optimal incor- poration of labelled substrates into ALA by isolated plastids}

Table IV A illustrates the effect of sodium levulinate (a competitive inhibitor of ALAdehydratase) (1) and various cofactors on the formation of ALA by isolated barley plastids. Levulinate ( $25 \mathrm{mM}$ ) caused a 24 -fold increase in

\section{Table IV A}

The cofactor requirements for the incorporation of $\alpha$ ketoglutarate- $\mathrm{U}-{ }^{14} \mathrm{C}$ into ALA by isolated barley plastids.

\begin{tabular}{l|r}
\hline Cofactors & \multicolumn{2}{c}{ cpm incorporated into ALA } \\
\cline { 2 - 2 } Complete & 184,834 \\
Complete - ATP & 91,487 \\
Complete- coenzyme A & 169,423 \\
Complete - $\mathrm{MgCl}_{2}$ & 170,728 \\
Complete - sodium acetate & 178,478 \\
Complete - FAD & 182,005 \\
Complete-sodium levulinate & 7,780 \\
- all & 8,913 \\
- all + sodium & \\
levulinate & 63,516 \\
\hline
\end{tabular}

Plastids were isolated from greening barley as under Material and Methods except that the $\mathrm{pH}$ of the grinding and suspension media was adjusted with $\mathrm{KOH}$ and the suspension medium contained 0.1 $\mathrm{M}-\mathrm{K}_{2} \mathrm{HPO}_{4}$ instead of $0.05 \mathrm{M}-\mathrm{Na}_{2} \mathrm{HPO}_{4}$. The complete incubation mixture contained in addition to the components of the suspension medium: $0.5 \mathrm{mM}-\mathrm{ATP}, 0.5$ $\mathrm{mM}-\mathrm{CoA}, 1 \mathrm{mM}-\mathrm{MgCl}_{2}, 10 \mu \mathrm{M}$-sodium acetate, $10 \mu \mathrm{M}$ FAD, $25 \mathrm{~mm}$-sodium levulinate, $2.5 \mu \mathrm{Ci}$ of $\alpha$-ketoglutarate- $\mathrm{U}-{ }^{14} \mathrm{C}$ and plastids containing $101 \mu \mathrm{g}$ chlorophyll. The incubation was for $20 \mathrm{~min}$ at $22^{\circ} \mathrm{C}$. the accumulation of labelled ALA. ATP stimulated ALA formation two-fold. A slight but consistent stimulation of the incorporation of label into ALA was observed with $1 \mathrm{~mm}$ $\mathrm{MgCl}_{2}, 10 \mu \mathrm{M}$-acetate and $10 \mu \mathrm{M}-\mathrm{FAD}$. Higher concentrations of $\mathrm{MgCl}_{2}$ tended to inhibit the incorporation of $a$-ketoglutarate- $1{ }^{14} \mathrm{C}$ into ALA while FAD and FMN at concentrations of $0.5 \mathrm{mM}$ or greater caused a $50 \%$ inhibition of ALA synthesis. Table IV B shows the stimulating effect of light. ALA formation was not stimulated by an oxygen atmosphere in the dark. Optimal incorporation of label into ALA was achieved under aerobic as compared to anaerobic conditions but oxygen did not improve the incorporation relative to aerobic conditions.

Neither oxidized nor reduced pyridine nucleotides added to isolated plastids showed any consistent effect on incorporation of labelled substrates into ALA. We were able, however, to ascertain that either NADPH or electron transport can provide the reducing power for the conversion of L-glutamate to ALA (Table V) by using photosynthetic inhibitors and electron donors to the two photosystems. The inhibitor of electron transport, DCMU, at a concentration of $3 \mu \mathrm{M}$, reduced ALA formation by $92 \%$ in isolated barley plastids. Plastids isolated from immature leaves of spinach were inhibited $25 \%$ at $3 \mu \mathrm{M}$ DCMU and $60 \%$ at $10 \mu \mathrm{M}-\mathrm{DCMU}$. The stimulation of ALA formation by ATP or in particular ADP was strongly counteracted by DCMU. We conclude that NADPH or electron 


\section{Table IV B}

The requirement of light and aerobic conditions for the incorporation of $\mathrm{L}$-glutamate- ${ }^{14} \mathrm{C}$ into $\mathrm{ALA}$ by isolated barley plastids.

cpm incorporated into ALA from:

Conditions L-glutamate-1-14 $\mathrm{C}$ L-glutamate-U- ${ }^{14} \mathrm{C}$

\begin{tabular}{l|c|c}
\hline $\begin{array}{l}\text { light } \\
\text { dark } \\
\text { dark, oxygen } \\
\text { atmosphere }\end{array}$ & $\begin{array}{r}18,697 \\
4,189\end{array}$ & - \\
$\begin{array}{l}\text { in light } \\
\text { aerobic } \\
\text { anaerobic } \\
\text { (nitrogen } \\
\text { atmosphere) } \\
\text { oxygen } \\
\text { atmosphere }\end{array}$ & - & - \\
\hline
\end{tabular}

Conditions as in Table IV A except for the following: the concentration of sodium acetate was $50 \mu \mathrm{M}$ and FAD was omitted. The plastids contained $4 \mu \mathrm{g}$ of chlorophyll for the L-glutamate- $1-{ }^{14} \mathrm{C}$ and $21 \mu \mathrm{g}$ for the L-glutamate-U- ${ }^{14} \mathrm{C}$ experiment. The incubations were carried out in $10 \mathrm{ml}$ plastic tubes in $0.2 \mathrm{ml}$ for a period of $15 \mathrm{~min}$ at $22^{\circ} \mathrm{C}$. Darkness was achieved by wrapping the tubes in 4 layers of aluminium foil and oxygen and nitrogen atmospheres by flushing the tubes and plastids, on ice, with these gases. The tubes were then sealed with rubber stoppers.

transport are required for the formation of ALA. The uncouplers $\mathrm{CCCP}, \mathrm{NH}_{4}{ }^{+}$, methylamine and hydroxylamine inhibit ALA formation from L-glutamate or $\alpha$-ketoglutarate by spinach chloroplasts. The effect of hydroxylamine with glutamate as substrate and that of methylamine with $\alpha$-ketoglutarate as a substrate is however weak. The inhibitory effect of the uncouplers can be reversed by ATP. ADP is about as efficient as ATP in compensating the inhibitory effect of CCCP on the incorporation of $\alpha$-ketoglutarate into ALA. The results with these uncouplers further support the notion that photosynthetic phosphorylation can provide the ATP to drive the formation of ALA.

The addition of PMS to a barley plastid preparation inhibited ALA formation. Since
PMS, besides stimulating cyclic photophosphorylation, also chemically oxidizes NADPH (17), this inhibition may mean that ALA formation requires NADPH or alternatively that PMS oxidizes a reduced intermediate between $a$-ketoglutarate and ALA. Ascorbate alone in the incubation mixture reduced ALA formation from labelled substrate by $25 \%$. However, in spinach, ascorbate and catalytic amounts of DCPIP or TMPD, stimulated the label incorporation into ALA by 150 and $50 \%$ respectively. Uncouplers such as methylamine and $\mathrm{CCCP}$ interfere with this stimulation. In an experiment with barley plastids DCPIP and ascorbate failed to stimulate ALA formation. In conclusion, the effects of photosynthetic inhibitors and electron donors reveal that the strong stimulation of the synthesis of ALA by light is due to an increased generation of ATP and NADPH.

In an attempt to determine the origin of the amino group in ALA we investigated the effect of a number of amino acids on the incorporation of $\alpha$-ketoglutarate $-{ }^{14} \mathrm{C}$ into ALA. None of the amino acids tested stimulated ALA formation (Table VI). As expected glutamate and glutamine inhibited the incorporation of $\alpha$ ketoglutarate into ALA by 95 and $53 \%$ respectively.

\subsection{The immediate precursor of ALA in isolated plastids}

In order to determine whether glutamate or $\alpha$-ketoglutarate is nearer to ALA in the biosynthetic pathway, we carried out a precursor competition experiment using 21.5 $\mu \mathrm{M}-\alpha$-ketoglutarate-U- ${ }^{14} \mathrm{C}$ and $5 \mu \mathrm{M}-\mathrm{L}$-glutamate-4- ${ }^{3} \mathrm{H}$ (Table VII). We attempted to influence the incorporation of these two labelled substrates into ALA by diluting one or the other of them through the addition of a 500 -fold higher amount of a-ketoglutarate or a 2000 -fold higher amount of glutamate.

As evident from Table VII the ${ }^{14} \mathrm{C}$-ketoglutarate had a lower specific activity than the ${ }^{3} \mathrm{H}$ glutamate. If tested separately a ratio of ${ }^{3} \mathrm{H}$ to ${ }^{14} \mathrm{C}$ counts of 1.7 was obtained (lines 1 and 2 ). When the two radioactive precusors were combined in the same reaction mixture the amount 
Table V

The effect of photosynthetic inhibitors and electron donor systems on the incorporation of L-glutamate-U-14 $\mathrm{C}$ and a-ketoglutarate-U- ${ }^{14} \mathrm{C}$ into $\mathrm{ALA}$ by isolated plastids from spinach and barley.

\begin{tabular}{|c|c|c|c|}
\hline \multirow[b]{3}{*}{ Compounds } & \multicolumn{3}{|c|}{ ALA formation ( $\%$ of control) } \\
\hline & \multicolumn{2}{|c|}{ Spinach } & \multirow{2}{*}{$\begin{array}{c}\text { Barley } \\
\text { glutamate }\end{array}$} \\
\hline & glutamate & $\alpha$-ketoglutarate & \\
\hline Control without ATP & 100 & 100 & 100 \\
\hline ATP, $0.5 \mathrm{mM}$ & - & 141 & 189 \\
\hline ADP, $0.5 \mathrm{mM}$ & - & 151 & 197 \\
\hline DCMU, $3 \mu \mathrm{M}$ & 75 & - & 8 \\
\hline DCMU, $10 \mu \mathrm{M}$ & 39 & 15 & 7 \\
\hline DCMU, $3 \mu \mathrm{M}+\mathrm{ATP}, 0.5 \mathrm{mM}$ & - & - & 52 \\
\hline DCMU, $3 \mu \mathrm{M}+\mathrm{ADP}, 0.5 \mathrm{mM}$ & - & - & 47 \\
\hline DCMU, $10 \mu \mathrm{M}+\mathrm{ATP}, 0.5 \mathrm{mM}$ & - & 37 & 47 \\
\hline DCMU, $10 \mu \mathrm{M}+\mathrm{ADP}, 0.5 \mathrm{mM}$ & - & 20 & 43 \\
\hline Methylamine, $60 \mathrm{~mm}$ & 29 & 86 & - \\
\hline Methylamine, $60 \mathrm{mM}+$ ATP, $0.5 \mathrm{mM}$ & 241 & 157 & - \\
\hline Methylamine, $60 \mathrm{mM}+$ ADP, $0.5 \mathrm{mM}$ & - & 141 & - \\
\hline Hydroxylamine, $0.5 \mathrm{mM}$ & 89 & - & - \\
\hline Hydroxylamine, $0.5 \mathrm{mM}+\mathrm{ATP}, 0.5 \mathrm{mM}$ & 100 & - & - \\
\hline $\mathrm{CCCP}, 3 \mu \mathrm{M}$ & 45 & 42 & - \\
\hline $\mathrm{CCCP}, 3 \mu \mathrm{M}+\mathrm{ATP}, 0.5 \mathrm{mM}$ & 166 & 97 & - \\
\hline $\mathrm{CCCP}, 3 \mu \mathrm{M}+\mathrm{ADP}, 0.5 \mathrm{mM}$ & 166 & 90 & - \\
\hline$\left(\mathrm{NH}_{4}\right)_{2} \mathrm{SO}_{4}, 5 \mathrm{mM}$ & 36 & - & - \\
\hline$\left(\mathrm{NH}_{4}\right)_{2} \mathrm{SO}_{4}, 5 \mathrm{mM}+\mathrm{ATP}, 0.5 \mathrm{mM}$ & 223 & - & - \\
\hline Phenazine methosulphate, $50 \mu \mathrm{M}$ & - & 32 & - \\
\hline Ascorbate, $10 \mathrm{~mm}$ & 75 & - & - \\
\hline Ascorbate, $10 \mathrm{mM}+$ DCPIP, $50 \mu \mathrm{M}$ & 253 & 249 & 84 \\
\hline Ascorbate, $10 \mathrm{mM}+$ DCPIP, $50 \mu \mathrm{M}+\mathrm{CCCP}, 3 \mu \mathrm{M}$ & - & 64 & - \\
\hline Ascorbate, $10 \mathrm{mM}+$ DCPIP, $50 \mu \mathrm{M}+$ Methylamine $60 \mathrm{mM}$ & - & 130 & - \\
\hline Ascorbate, $10 \mathrm{mM}+\mathrm{TMPD}, 100 \mu \mathrm{M}$ & 144 & - & - \\
\hline
\end{tabular}

of ${ }^{3} \mathrm{H}$-glutamate incorporated decreased relatively more than that of ${ }^{14} \mathrm{C}$-ketoglutarate as is expected from the higher molar concentration of the radioactive $\alpha$-ketoglutarate. The ratio of ${ }^{3} \mathrm{H}$ to ${ }^{14} \mathrm{C}$ counts was 1.2 (line 3). The addition of a 500 -fold excess of cold $\alpha$ ketoglutarate raised this ratio to 20.1 (line 4). The addition of a 2000 -fold excess of cold glutamate also increased this ratio, to 3.5 (line $5)$, because the decrease of label incorporation from $\alpha$-ketoglutarate was greater than that from glutamate (cf. line 5 and 3). Aminooxyacetate inhibits transamination and is therefore expected to affect the incorporation of $a$ ketoglutarate and glutamate. An increase of the ratio of ${ }^{3} \mathrm{H}$, to ${ }^{14} \mathrm{C}$ counts to a value of 12.4 is observed by the addition of this inhibitor (line 6). Clearly the incorporation of radioactive glutamate is favoured relative to that of $a$ ketoglutarate. However, the incorporation of glutamate is also inhibited by aminooxyacetate indicating the involvement of a transamination reaction in the conversion of glutamate into ALA. If this inhibitor is combined with an excess of cold $\alpha$-ketoglutarate the ratio of ${ }^{3} \mathrm{H}$ to ${ }^{14} \mathrm{C}$ counts climbs to 35.0 (line 7) resulting from the very low incorporation of ${ }^{14} \mathrm{C}-\alpha$ ketoglutarate into ALA. This double label experiment shows glutamate to be preferentially incorporated into ALA, when a-ketoglutarate 
Table VI

The effect of several amino acids on the incorporation of $\alpha$-ketoglutarate-1-14 $\mathrm{C}$ into ALA with isolated spinach plastids.

\begin{tabular}{l|c}
\hline $\begin{array}{l}\text { Amino acid added } \\
(5 \mathrm{mM})\end{array}$ & cpm incorporated into ALA \\
\hline none & 27,121 \\
glycine & 24,210 \\
L-tyrosine & 27,564 \\
L-phenylalanine & 19,949 \\
L-tryptophan & 22,261 \\
L-glutamine & 12,851 \\
L-alanine & 23,208 \\
L-lysine & 19,813 \\
L-cysteine & 18,297 \\
L-glutamate & 1,373 \\
L-serine & 23,834 \\
\hline
\end{tabular}

Plastids were isolated from immature leaves of spinach in HONDA medium and suspended in $0.1 \mathrm{M}-2$ ( $\mathrm{N}$-2-hydroxyethylpiperazin- $\mathrm{N}^{\prime}$-yl) ethanesulphonic acid, $0.1 \mathrm{M}-\mathrm{K}_{2} \mathrm{HPO}_{4}, 1.0 \mathrm{mM}$-dithiothreitol at $\mathrm{pH} 7.9$. Incubations were carried out in a total volume of 2.0 $\mathrm{ml}$ containing the components of the suspension medium and in addition $25 \mathrm{~mm}$-sodium levulinate, $262 \mu \mathrm{g}$ chlorophyll and $2.5 \mu \mathrm{Ci}$ of a-ketoglutarate- $1{ }^{14} \mathrm{C}$. Incubations were for $15 \mathrm{~min}$ at $22^{\circ} \mathrm{C}$ in the bright light. and L-glutamate are supplied to isolated plastids under competitive conditions. The results are consistent with a pathway, where $\alpha$ ketoglutarate is converted to ALA via glutamate.

\subsection{ALA synthesis by isolated chloroplasts from unlabelled and labelled substrate and product characterization}

Intact chloroplasts isolated from greening barley formed ALA in quantities large enough to allow spectrophotometric assays. The ALA made by plastids endogenously or with addition of glutamate as substrate (Table VIIL) was assayed by deriving the pyrrole and adding Ehrlich reagent (7). The resulting spectrum had the same form as that observed with authentic ALA-pyrrole with an $A_{525} / A_{553}$ ratio of 0.67 . The putative pyrrole derivative was also chromatographed on thin layer plates (7) and the spot detected by pink colour upon spraying with Ehrlich reagent. The spot had a $R_{f}$ value identical to that of authentic ALA-pyrrole. As seen from Table VIII, 4.7 nmoles of ALA were formed by plastids without addition of substrate. This amount increased to 6.4 nmoles upon addition of $0.1 \mathrm{~mm}$-glutamate. The plastid

Table VII

Precursor competition experiment for ALA formation by isolated barley plastids.

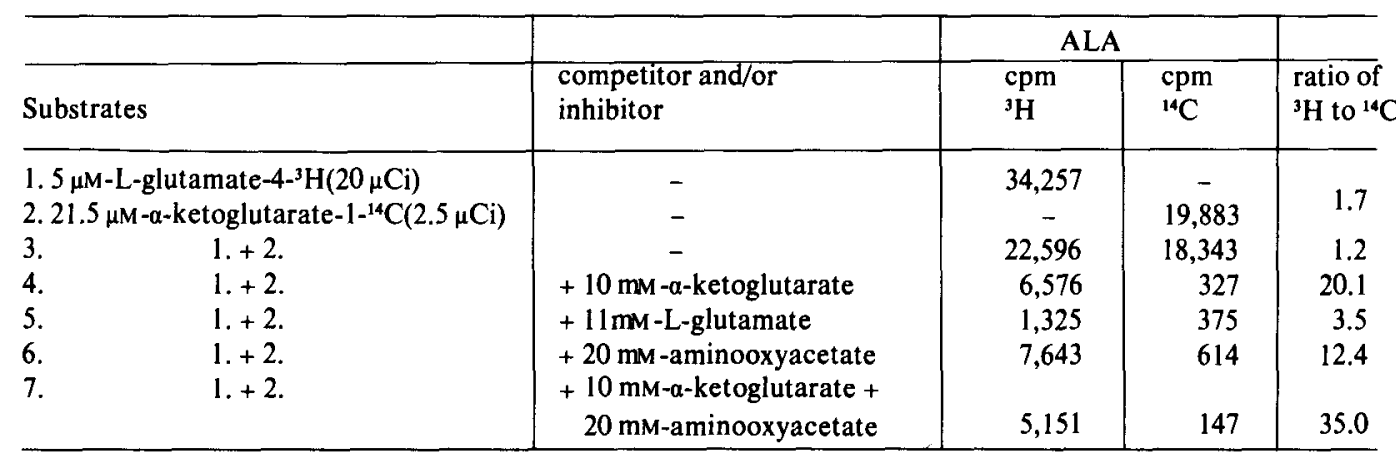

Leaves were harvested from 6-day dark grown and 6 hours greened plants and stored overnight at $4^{\circ} \mathrm{C}$. Plastids were isolated in $0.6 \mathrm{M}$-glycerol, $0.1 \mathrm{M}$-Tricine, $3 \mathrm{mM}-\mathrm{Ca}\left(\mathrm{NO}_{3}\right)_{2}$ and suspended in $0.3 \mathrm{M}-\mathrm{glycerol}, 0.1 \mathrm{M}-\mathrm{Tricine}, 50$ $\mathrm{mM}-\mathrm{Na}_{2} \mathrm{HPO}_{4}, 1 \mathrm{~mm}$ dithiothreitol. The $\mathrm{pH}$ of both media was adjusted to 7.9 with $\mathrm{NaOH}$. The incubation medium in $2 \mathrm{ml}$ contained in addition to the components of the suspension medium the following: $0.5 \mathrm{mM}-\mathrm{ATP}, 0.33 \mathrm{mM}$ coenzyme A, $1 \mathrm{~mm}-\mathrm{MgCl}_{2}, 10 \mu \mathrm{M}$-acetate, $10 \mu \mathrm{MFAD}, 25 \mathrm{~mm}$-levulinate, the substrates and $65 \mu \mathrm{g}$ chlorophyll. Samples were incubated for $10 \mathrm{~min}$ at $22^{\circ} \mathrm{C}$ in light. 
Table VIII

Effect of increasing glutamate concentrations on ALA accumulation in isolated barley plastids.

\begin{tabular}{l|c|c}
\hline $\begin{array}{c}\text { Amount of } \\
\text { glutamate } \\
\text { added }\end{array}$ & $\begin{array}{c}\text { Time of } \\
\text { incubation } \\
\text { min }\end{array}$ & $\begin{array}{c}\text { nmoles of } \\
\text { ALA } \\
\text { observed }\end{array}$ \\
\hline 0 & 0 & 0.8 \\
0 & 15 & 4.7 \\
$0.01 \mathrm{mM}$ & 15 & 5.7 \\
$0.1 \mathrm{mM}$ & 15 & 6.4 \\
$1.0 \mathrm{mM}$ & 15 & 6.2 \\
$5.0 \mathrm{mM}$ & 15 & 5.7 \\
\hline
\end{tabular}

Plastids were isolated from 4-day dark grown and 6 hours greened leaves in $0.6 \mathrm{M}$-glycerol, $0.1 \mathrm{M}$-Tricine, $3 \mathrm{~mm}-\mathrm{Ca}\left(\mathrm{NO}_{3}\right)_{2}, \mathrm{pH} 7.9$ and were suspended in 0.3 $\mathrm{M}$-glycerol, $0.1 \mathrm{M}$-Tricine, $0.1 \mathrm{M}-\mathrm{K}_{2} \mathrm{HPO}_{4}, 1 \mathrm{mM}$-dithiothreitol, $\mathrm{pH}$ 7.9. Plastids were incubateo in $2 \mathrm{ml}$ containing the components of the suspension medium and in addition $0.5 \mathrm{mM}$-ATP, $25 \mathrm{~mm}$-sodium levulinate and $180 \mu \mathrm{g}$ chlorophyll at $22^{\circ} \mathrm{C}$ under bright light. The ALA formed was assayed using the usual procedure except for the following. A small amount of radioactive ALA was added before acidification of the reaction mixture. After extraction of the ALA-pyrrole into ether at $\mathrm{pH} 4.5$ the recovery of ALA was determined by counting a portion of ether. A drop of concentrated ammonia was added to the rest of the ether, it was evaporated and the ALA-pyrrole redissolved in a small volume of water and an equal volume of modified Ehrlich reagent. The ALA was then determined spectrophotometrically.

preparation that yielded these amounts of ALA contained $180 \mu \mathrm{g}$ of chlorophyll per reaction mixture. This chlorophyll has been synthesized over a six hour period and it is therefore possible to estimate the amount of chlorophyll which the plastids would have made in $15 \mathrm{~min}$ in the leaf, assuming a roughly linear rate of.synthesis: $\frac{180}{0,893} \times \frac{1}{24}=8.40$ nmoles which correspond to 67.2 nmoles of ALA. With added substrate the plastids have thus formed in vitro a substantial amount of ALA.

Radioactive product formed by isolated barley chloroplasts from $\alpha$-ketoglutarate $-1-{ }^{14} \mathrm{C}$ was characterized in the following manner:

Cold authentic ALA was added to the reaction mixture and ALA purified as usual by
Dowex cation exchange chromatography (7). The fraction containing ALA was eluted with a potassium acetate buffer $\left(0.2 \mathrm{M}-\mathrm{K}^{+}, \mathrm{pH}\right.$ adjusted to 5.1 with acetic acid) and subjected to paper chromatography using butanol, acetic acid, water, 2.5:4:10, v/v/v after removal of $\mathrm{K}^{+}$ as perchlorate. There were two radioactive peaks with the $R_{f}$ 's of glutamate (0.1) and ALA (0.43) respectively. The ALA was eluted and its specific activity determined to be $62 \mathrm{cpm} /$ $\mu$ mole. The ALA-pyrrole was then prepared and chromatographed on thin layer plates (7). The specific activity was determined to be 68 $\mathrm{cpm} / \mu \mathrm{mole}$, thus approximating that of the ALA. This purification to constant specific activity confirms the identification of the product as ALA.

\subsection{The effect of metabolic inhibitors and other compounds on ALA formation in isolated plastids}

Three compounds significantly inhibited ALA formation from ${ }^{14} \mathrm{C}$-glutamate in isolated plastids: aminooxyacetate, DL- $\beta$-hydroxyglutamate and glyoxylate (Table IX). Glycollate was not inhibitory at the highest concentration (20 mM) tested.

Azide and cyanide, at low concentrations, had no significant effect on the incorporation of glutamate into ALA, whereas at a concentration of $5 \mathrm{mM}$ these compounds inhibited by about $30 \%$. Fifty mM-EDTA inhibited by $30 \%$. $\alpha \alpha$-Dipyridyl at a concentration of $0.5 \mathrm{~mm}$ stimulated by $50 \%$ but increasing the concentration to $10 \mathrm{~mm}$ gave a $50 \%$ inhibition. Compounds tested and found to have no inhibitory effect on the incorporation of labelled $a$ ketoglutarate or L-glutamate by barley plastids into ALA were: $\mathrm{NaF}(0.1$ to $5 \mathrm{~mm}), \mathrm{FeSO}_{4}$ $(0.005$ to $1 \mathrm{mM})$, Antimycin $\mathrm{A}(0.1 \mu \mathrm{M}$ to $50 \mu \mathrm{M})$ Folic acid $(0.1 \mathrm{mM}$ to $5 \mathrm{mM})$, amethopterin $(0.1$ to $5 \mathrm{mM})$, heme $(100 \mu \mathrm{M})$, protoporphyrin (29 $\mu \mathrm{M}), \delta$-aminolevulinate $(0.75 \mathrm{mM}), \quad$ and porphobilinogen $(100 \mu \mathrm{M})$.

\subsection{Chlorophyll synthesis in isolated plastids}

Levulinate is a competitive inhibitor of ALA dehydratase from Chlorella (1). In our experi- 
Table IX

Inhibition of the incorporation of L-glutamate-U-14 $\mathrm{C}$ into ALA by plastids.

\begin{tabular}{|c|c|c|c|}
\hline Experiment & Inhibitor mM & & $\begin{array}{l}\text { ALA formation } \\
\% \text { of control }\end{array}$ \\
\hline 1. Barley plastids & Aminooxyacetate & $\begin{array}{l}0.05 \\
5 \\
20 \\
50\end{array}$ & $\begin{array}{r}80 \\
72 \\
37 \\
5\end{array}$ \\
\hline 2. Barley plastids & DL- $\beta$-hydroxyglutamate & $\begin{array}{l}0.005 \\
0.01 \\
0.05 \\
1 \\
5\end{array}$ & $\begin{array}{c}66 \\
46 \\
4 \\
1.5 \\
0.5\end{array}$ \\
\hline 3. Maize plastids & Glyoxylate & $\begin{array}{l}0.1 \\
1.5 \\
20\end{array}$ & $\begin{array}{l}95 \\
82 \\
13\end{array}$ \\
\hline
\end{tabular}

Plastids were isolated from barley grown for six days and maize for eight days in the dark and greened for 6-7 hours. The isolation media contained $0.1 \mathrm{M}$-Tricine, $3 \mathrm{~mm}-\mathrm{Ca}\left(\mathrm{NO}_{3}\right)_{2}, 0.6 \mathrm{M}$-sorbitol for experiment 1 and $0.6 \mathrm{M}$ glycerol for experiments 2 and 3. The pH was adjusted to 7.9 with $\mathrm{KOH}$ in experiment 1 and with $\mathrm{NaOH}$ in experiments 2 and 3. Incubation media contained: in experiment $1,0.3 \mathrm{M}$-sorbitol, $0.1 \mathrm{M}$-Tricine, $0.1 \mathrm{M}-\mathrm{K}_{2} \mathrm{HPO}_{4}, 25$ mM-sodium levulinate, $2.5 \mu \mathrm{Ci} \mathrm{L-glutamate-U}-{ }^{14} \mathrm{C}, 82 \mu \mathrm{g}$ chlorophyll, $\mathrm{pH}$ adjusted to 7.9 with $\mathrm{KOH}$; in experiment 2, 0.3 M-glycerol, $0.1 \mathrm{M}$-Tricine, $50 \mathrm{mM}-\mathrm{Na}_{2} \mathrm{HPO}_{4}, 25 \mathrm{~mm}$-sodium levulinate, $2.5 \mu \mathrm{Ci} \mathrm{L}$-glutamate-U- ${ }^{14} \mathrm{C}, 0.5$ mM-ATP, $0.5 \mathrm{~mm}-\mathrm{CoA}, 1 \mathrm{mM}-\mathrm{MgCl}_{2}, 10 \mu \mathrm{M}$-sodium acetate, $107 \mu \mathrm{g}$ chlorophyll, $\mathrm{pH}$ adjustment to 7.9 with $\mathrm{NaOH}$; in experiment 3, $0.3 \mathrm{M}$-glycerol, $0.1 \mathrm{M}$-Tricine, $50 \mathrm{mM}-\mathrm{Na}_{2} \mathrm{HPO}_{4}, 25 \mathrm{~mm}$-sodium levulinate, $2.5 \mu \mathrm{Ci} \mathrm{L}$ glutamate-U- ${ }^{14} \mathrm{C}, 0.5 \mathrm{~mm}-\mathrm{ATP}, 0.5 \mathrm{~mm}-\mathrm{CoA}, 1 \mathrm{~mm}-\mathrm{MgCl}_{2}, 10 \mu \mathrm{M}$-sodium acetate, $10 \mu \mathrm{M}-\mathrm{FAD}, 56 \mu \mathrm{g}$ chlorophyll, $\mathrm{pH}$ adjustment to 7.9 with $\mathrm{NaOH}$. Incubations were for $15 \mathrm{~min}$ at $22^{\circ} \mathrm{C}$ in experiment 1 under bright light and experiments 2 and 3 under less intense light.

ments to study ALA synthesis from labelled glutamate or $\alpha$-ketoglutarate in isolated plastids this inhibitor was always included in the incubation mixture. When levulinate was left out the label from L-glutamate- $-1{ }^{14} \mathrm{C}$ or $-\mathrm{U}-{ }^{14} \mathrm{C}$ appeared in several compounds. We have identified one of these as chlorophyll $a$, while two others have been tentatively identified as protoporphyrin IX and Mg-protoporphyrin IX monomethylester by extraction of pigments into ether and chromatography. The pigments extracted into ether at $\mathrm{pH} 7.9$ contained radioactivity associated with chlorophyll $a$ (Figure 7 B). Table $X$ shows that the pheophytin $a$ and pheophorbide $a$ prepared from this chromatographically purified chlorophyll $a$ had specific activities closely similar to the chlorophyll $a$. The label is thus not associated with the phytol.
The distribution of label from L-glutamate$\mathrm{U}-{ }^{14} \mathrm{C}$ into ALA and chlorophyll in the presence and absence of levulinate is shown in Table XI. It can be seen that one third of the radioactivity which is incorporated into ALA is channeled into chlorophyll $a$ when levulinate is absent. We therefore conclude that the radioactivity from L-glutamate- $1-{ }^{14} \mathrm{C}$ or $\mathrm{U}-{ }^{14} \mathrm{C}$ is incorporated into chlorophyll $a$. Thin layer chromatographic analysis of the $\mathrm{pH} 5.5$ ether extract revealed two other labelled bands (Figure $7 \mathrm{C}$ ). A slow moving compound with an $R_{f}$ of 0.23 cochromatographed with authentic protoporphyrin IX in the lutidine:water:ammonia system. The fast moving radioactive band had an $R_{f}$ of 0.68 corresponding to a monocarboxylie porphyrin. We suspect this to be $\mathrm{Mg}$ protoporphyrin IX monomethylester. 


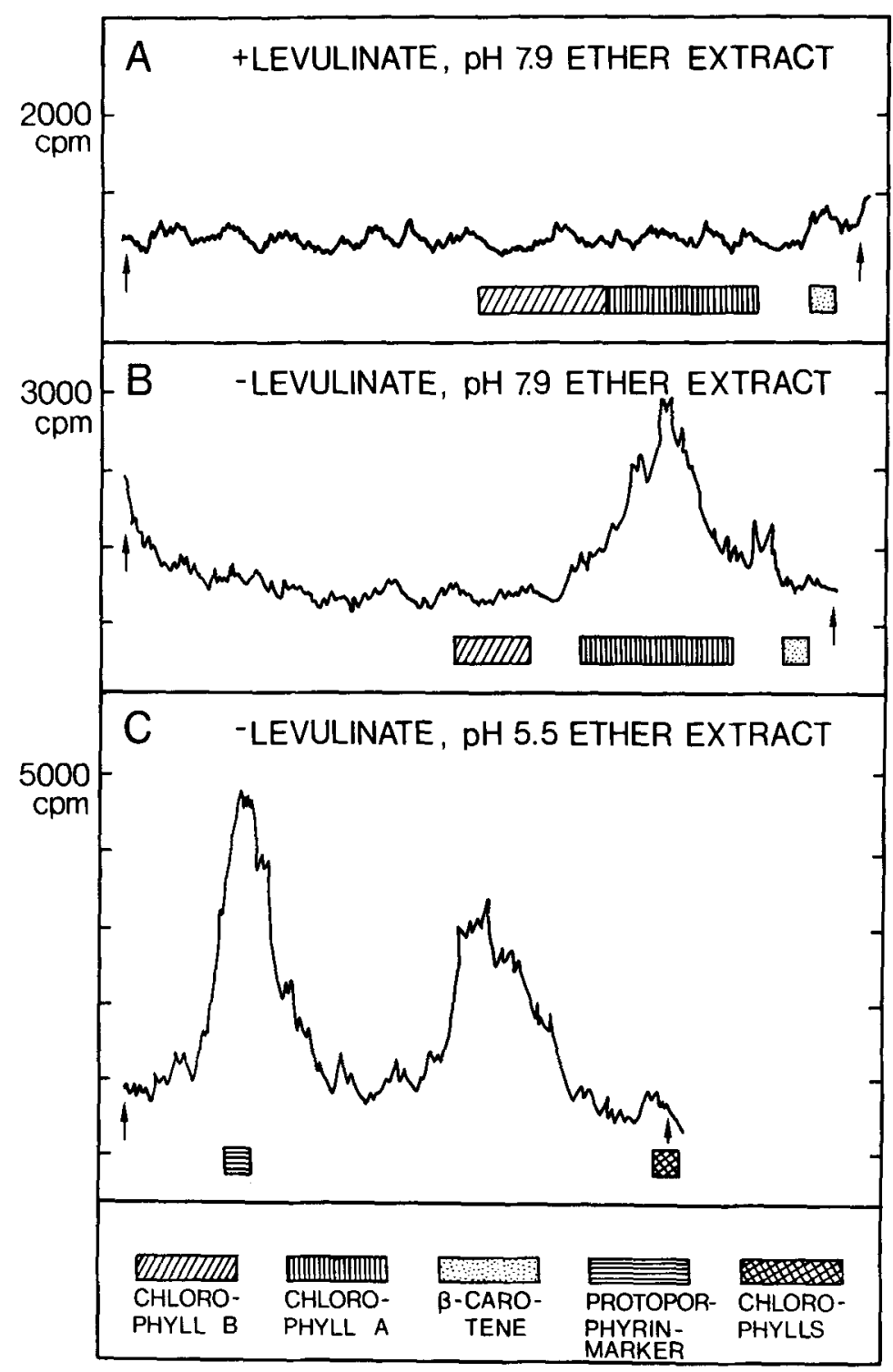

Figure 7. Radiochromatograms of ether soluble pigments from greening plastids of barley incubated with ${ }^{14} \mathrm{C}$ labelled glutamate in the presence and absence of levulinate. A. In the presence of levulinate no label from glutamate- $\mathrm{U}-{ }^{14} \mathrm{C}$ is incorporated into chlorophyll $a$ or $b$. The location of the visible bands for chlorophyll $a, b$ and $\beta$-carotene are indicated below the radioactivity trace. $\mathrm{B}$. In the absence of levulinate glutamate-1 $-{ }^{14} \mathrm{C}$ is incorporated into chlorophyll $a$. C. In the absence of levulinate glutamate- $\mathrm{U}-{ }^{14} \mathrm{C}$ is also incorporated into porphyrins with a chromatographic behaviour corresponding to protoporphyrin IX and monocarboxylic porphyrin(s) (right hand peak). Developing solvent systems used, A and B, system 1; C, system 3. Origin, arrows to left; solvent front, arrows to right. 
Table X

Identification of ${ }^{14} \mathrm{C}$-chlorophyll $a$ by degradation and determination of specific activity.

\begin{tabular}{|c|c|c|}
\hline \multirow[b]{2}{*}{ Pigment } & \multicolumn{2}{|c|}{ Specific activity cpm per $\mu$ mole } \\
\hline & $\begin{array}{c}\text { L-glutamate } \\
-1-1{ }^{14} \mathrm{C}\end{array}$ & $\begin{array}{c}\text { L-glutamate } \\
-\mathrm{U}-{ }^{14} \mathrm{C}\end{array}$ \\
\hline Chlorophyll $a$ & 696,540 & 705,470 \\
\hline Pheophytin $a$ & 659,571 & - \\
\hline Pheophorbide $a$ & 637,689 & 613,231 \\
\hline
\end{tabular}

Isolated chloroplasts were incubated with L-glutamate- $1-{ }^{14} \mathrm{C}$ and $-\mathrm{U}-{ }^{14} \mathrm{C}$ and radioactivities corresponding to chlorophyll $a$ were purified, degraded by acid hydrolysis and analysed as described under Materials and Methods.

\section{Table XI}

Distribution of radioactivity in chlorophyll $a$ and $\delta$ aminolevulinate in the presence and absence of levulinate.

\begin{tabular}{l|c|c}
\hline & \multicolumn{2}{|c}{ cpm incorporated into: } \\
Experiment & $\begin{array}{c}\text { not } \\
\text { chlorophyll }\end{array}$ & ALA \\
\hline $\begin{array}{l}\text { devulinate } \\
\text { lectable }\end{array}$ & 105,922 \\
- 25 mM-sodium & 29,367 & 12,652 \\
\hline levulinate & & \\
\hline
\end{tabular}

Chloroplasts were isolated from 6-day dark grown barley seedlings greened for 6 hours and incubated in medium containing $0.3 \mathrm{M}$-glycerol, $0.1 \mathrm{M}$-Tricine, $50 \mathrm{~mm}-\mathrm{Na}_{2} \mathrm{HPO}_{4}, 1 \mathrm{~mm}$-dithiothreitol, $0.5 \mathrm{~mm}-\mathrm{ATP}$, $0.5 \mathrm{~mm}-\mathrm{CoA}, 1 \mathrm{~mm}-\mathrm{MgCl}_{2}, 10 \mu \mathrm{M}$-acetate, $10 \mu \mathrm{M}-\mathrm{FAD}$, $2.5 \mu \mathrm{Ci}$ L-glutamate- $U-{ }^{14} \mathrm{C}$ and $50 \mu \mathrm{g}$ chlorophyll in a total volume of $2 \mathrm{ml}$. Incubations were carried out for $15 \mathrm{~min}$ at $22^{\circ} \mathrm{C}$ in light.

\section{DISCUSSION}

The plastid preparations studied synthesized ALA in significant quantities in the presence of levulinate and were able to carry out the long series of biochemical reactions leading to the formation of chlorophyll $a$ in the absence of the inhibitor. NADLER \& GRANICK (13) concluded from their studies that the enzyme involved in the synthesis of ALA during greening had a half-life of $90 \mathrm{~min}$. The ability of the isolated plastids to synthesize ALA decays with a halflife of $5 \mathrm{~min}$ during the incubation. Further studies will have to elucidate if the low stability of the ALA forming capacity of isolated plastids is related to the fast turnover of the enzyme in vivo.

In isolated plastids $\alpha$-ketoglutarate is incorporated more effectively into ALA than glutamate. On the other hand, in precursor competition experiments with $\alpha$-ketoglutarate, glutamate appears to be the more immediate precursor. These results indicate that $\alpha$ ketoglutarate is taken up more efficiently than glutamate and that the conversion of $\alpha$ ketoglutarate into glutamate is rapid.

Aminooxyacetate is known as a transaminase inhibitor in bacteria and animals (18). In Chlorella it was successfully used for inhibition of transaminase reactions in measurements of glutamate synthase activity (11). ALA formation from glutamate and $\alpha$-ketoglutarate by isolated plastids is inhibited by aminooxyacetate, indicating the involvement of transamination. In the precursor competition experiment (Table VII) we observed that $\alpha$ ketoglutarate incorporation into ALA was more strongly inhibited by aminooxyacetate than glutamate incorporation. This indicates that both the convertion of $\alpha$-ketoglutarate to glutamate and of glutamate to ALA involves a transaminase reaction. Glyoxylate inhibits the dioxovalerate transaminase of $\mathrm{R}$. spheroides (14). The inhibition of ALA formation by glyoxylate in maize plastids reported here is interesting in the light of the claim by LOHR \& FRIEDMAN (12) that ALA formation proceeds by way of dioxovaleric acid. The very strong inhibition of ALA formation that we observe with DL- $\beta$-hydroxyglutamate is surprising. It could compete with glutamate for uptake into the chloroplast or for the active site of the ALAsynthesizing enzyme or act as an irreversible inhibitor.

The plastid preparations from greening barley seedlings described in this paper provide a suitable active starting material for the isolation and purification of the different enzymes catalyzing the conversion of glutamate into chlorophyll $a$. 


\section{ACKNOWLEDGEMENTS}

We thank the following people for their help: Ms. Susanne Placing for her technical assistance, Mr. BøRGE Petersen for growing plants, Mss. NINA RASMUSSEN and ANN-SOFI STEINHOLTZ for drawing and photographic assistance, Ms. LENA KonGSRUd for typing, Dr. DAVID SIMPSON for electron microscopy and helpful discussions, professor DITER vON WETTSTEIN for helpful suggestions and a critical reading of the manuscript.

This work has been supported by grant GM22051 of the US PHS, National Institutes of Health to professor D. vON WETTSTEIN.

\section{REFERENCES}

1. BEALE, S. I.: The biosynthesis of $\delta$-aminolevulinic acid in Chlorella. Plant Physiol. 45, 504-406 (1970)

2. Beale, S. I. \& P. A. Castelfranco: The biosynthesis of $\delta$-aminolevulinic acid in higher plants I. Accumulation of $\delta$-aminolevulinic acid in greening plant tissues. Plant Physiol. 53, 291296 (1974)

3. Beale, S. I. \& P. A. Castelfranco: The biosynthesis of $\delta$-aminolevulinic acid in higher plants II. Formation of ${ }^{14} \mathrm{C} \cdot \delta$-aminolevulinic acid from labelled precursors in greening plant tissues. Plant Physiol. 53, 297-303 (1974)

4. Beale, S. I., S. P. Gough \& S. Granick: Biosynthesis of $\delta$-aminolevulinic acid from the intact carbon skeleton of glutamic acid in greening barley. Proc. Nat. Acad. Sci. USA 72, 2719-2723 (1975)

5. BRUINSMA, J.: A comment on the spectrophotometric determination of chlorophyll. Biochim. Biophys. Acta 52, 576-578 (1961)

6. Gough, S. P.: Defective synthesis of porphyrins in barley plastids caused by mutations in nuclear genes. Biochim. Biophys. Acta 286, 36-54 (1972)

7. Gough, S. P. \& C. G. Kannangara: Synthesis of $\delta$-aminolevulinic acid by isolated plastids. Carlsberg Res. Commun. 41, 183-190(1976)

8. Holden, M. Separation by paper chromatography of chlorophyll $a$ and $b$ and some of their breakdown products. Biochim. Biophys. Acta 56, 378-379 (1962)

9. KAHN, A., N. Avivi-Bleiser \& D. vON WETTSTEIN: Genetic regulation of chlorophyll biosynthesis analysed with double mutants in barley. In: Genetics and Biogenesis of Chloroplasts and Mitochondria. Th. Bücher et al. eds., Elsevier, North Holland Biomedical Press, Amsterdam pp 119-131 (1976)

10. Kannangara, C. G., S. P. Gough, B. Hansen, J. N. RASMUSSEN \& D. J. Simpson: A homogenizer with replaceable razor blades for bulk isolation of active barley plastids. Carlsberg Res. Commun. $42,431-440$ (1977)

11. LEA, P. J. \& B. J. MifLIN: The occurrence of glutamate synthase in algae. Biochem. Biophys. Res. Comm. 64, 856-862 (1975)

12. Lohr, J. B. \& H. C. Friedman: New pathway for $\delta$-aminolevulinic acid biosynthesis: Formation from $\alpha$-ketoglutaric acid by two partially purified plant enzymes. Biochem. Biophys. Res. Comm. $69,908-913(1976)$

13. Nadler, K. \& S. Granick: Controls on chlorophyll synthesis in barley. Plant Physiol 46, 240-246 (1970)

14. Neuberger, A. \& J. M. Turner: $\gamma$-Dioxovalerate aminotransferase activity in Rhodopseudomonas spheroides. Biochim. Biophys. Acta 67, 342-345 (1963)

15. NOBEL, P. S.: Chloroplast reflection coefficients: Influence of partition coefficients, carriers and membrane phase transitions. In: Membrane Transport in Plants. U. Zimmerman \& J. Dainty eds., Springer-Verlag, Berlin pp 289-295 (1974)

16. Smith, L. W., R. W. Breidenbach \& D. RUBENSTEIN: Thin layer chromatography of plant pigments on mannitol or sucrose. Science 148, 508-509 (1965)

17. TREBST, A.: Measurement of Hill reactions and photoreduction. In: Methods in Enzymology Vol. XXIV, A. San Pietro ed., Academic Press, New York p 162 (1972)

18. WEBB, J. L: Enzyme and Metabolic Inhibitors, Vol. II, Academic Press, New York pp 358-359 (1966)

19. Weinstein, J. D. \& P. A. Castelfranco: Protoporphyrin IX biosynthesis from glutamate in isolated greening chloroplasts. Arch. Biochem. Biophys. 178, 671-673 (1977)

20. Weinstein, J. D. \& P. A. Castelfranco: Incorporation of ${ }^{14} \mathrm{C}$-glutamate in 5-aminolevulinic acid (ALA) by isolated chloroplasts. Plant Physiol. 59, suppl. p 92 (1977)

21. Wettstein, D. von, A. Kahn, O. F. Nielsen \& S. P. Gough: Genetic regulation of chlorophyll biosynthesis analysed with mutants in barley. Science $184,800-802$ (1974) 